\title{
Poly(3-hydroxybutyrate): Promising biomaterial for bone tissue engineering
}

BARBARA DARIŠ $\breve{1}^{, *}$

ŽELJKO KNEZ1,2

${ }^{1}$ University of Maribor, Faculty of Medicine, Institute of Biomedical Sciences Maribor, Slovenia

${ }^{2}$ University of Maribor, Faculty of Chemistry and Chemical Engineering Laboratory for Separation Processes Maribor, Slovenia
Accepted February 26, 2019

Published online April 25, 2019

Poly(3-hydroxybutyrate) is a natural polymer, produced by different bacteria, with good biocompatibility and biodegradability. Cardiovascular patches, scaffolds in tissue engineering and drug carriers are some of the possible biomedical applications of poly(3-hydroxybutyrate). In the past decade, many researchers examined the different physicochemical modifications of poly(3-hydroxybutyrate) in order to improve its properties for use in the field of bone tissue engineering. Poly(3-hydroxybutyrate) composites with hydroxyapatite and bioglass are intensively tested with animal and human osteoblasts in vitro to provide information about their biocompatibility, biodegradability and osteoinductivity. Good bone regeneration was proven when poly(3-hydroxybutyrate) patches were implanted in vivo in bone tissue of cats, minipigs and rats. This review summarizes the recent reports of in vitro and in vivo studies of pure poly(3-hydroxybutyrate) and poly(3-hydroxybutyrate) composites with the emphasis on their bioactivity and biocompatibility with bone cells.

Keywords: poly(3-hydroxybutyrate), biopolymers, bone tissue engineering, osteoblasts

\section{INTRODUCTION}

A biomaterial can be defined as a natural or synthetic material suitable for interacting with biological systems, with a function to treat, augment or replace any tissue or organ (1). Biodegradable and biocompatible natural or synthetic polymers are referred to as "biomaterials" (2). Biomaterials for bone tissue engineering should fulfill the following requirements (3-5):

- Mechanical strength to withstand hydrostatic pressure. Young's modulus of cortical bone is between 15 and $20 \mathrm{GPa}$ and that of cancellous bone is between 0.1 and $2 \mathrm{GPa}$. Compressive strength varies between 100 and $200 \mathrm{MPa}$ for cortical bone, and between 2 and $20 \mathrm{MPa}$ for cancellous bone (5). The large variation in mechanical properties and geometry makes it difficult to design an "ideal" bone scaffold.

\footnotetext{
* Corresponding author; e-mail address: barbara.daris@um.si
} 
- Biocompatibility to induce new tissue formation without inflammation.

- Surface properties that suit osteogenic cells. For growth, proliferation and differentiation of cell hierarchical structure is crucial.

- Osteoinductivity to promote migration of osteogenic cells and to stimulate differentiation. An important role in osteoinductivity is played by chemical composition of the scaffold, porosity, surface properties and nano/micro topography.

- Porosity to allow cell ingrowth and neovascularization. Porosity is essential for diffusion of nutrients and for removal of metabolic wastes resulting from cellular activity. Pore size should be at least $100 \mu \mathrm{m}$ in diameter for successful diffusion of essential nutrients and oxygen. However, pore size in the range of 200 to $350 \mu \mathrm{m}$ was found to be optimal for bone tissue in-growth $(4,5)$.

- Vascularity to stimulate angiogenesis. Lack of vasculature leads to ischemia and cell apoptosis.

- Bioresorbability after scaffold degradation to allow new bone tissue to grow. The scaffold should degrade at a controlled resorption rate, creating space for the new bone tissue to grow. Degradation products should not cause inflammation to the surrounding tissue (3-5).

Biodegradable and biocompatible polyesters are being investigated worldwide for pharmacological, biomedical and environmental purposes (6). Polyhydroxyalkanoates (PHA) are natural polyesters produced by bacteria as intracellular carbon and energy sources when essential nutrients are limited and carbon is available (7). Poly(3-hydroxybutyrate) (PHB) is one of the best-known polymers of the PHA family (8). PHB is a homopolymer of (R)-3-hydroxybutyrate units (Fig. 1). Its molecular mass can range from 200 to up to $20,000(9,10)$.

Molecular mass of PHB is a very important feature to consider in PHB applications, because it determines the mechanical properties of the polymer and, in turn, the final application. Mechanical and thermal properties of PHB are high crystallinity (60-70\%), high melting temperature $\left(175^{\circ} \mathrm{C}\right)$, good tensile strength $(30-35 \mathrm{MPa})$ and appropriate elasticity modulus $(3 \mathrm{GPa})(11,12)$. It is a promising material for biomedical applications because it is a natural, renewable, biodegradable and biocompatible thermoplastic (13). PHB decomposes to 3-hydroxybutyric acid, which is also normally found in human blood (14). 3-Hydroxybutyric acid increases calcium influx in cultured cells and suppresses their death (15). In nature, PHB is degraded by the action of non-specific lipases and esterases. Therefore, lipases and esterases are presumably the enzymes that degrade PHB implants and their medical devices in vivo (16). Furthermore, sterilization of PHB-based materials does not affect the mechanical or chemical properties (17). Nevertheless, for packing materials, tissue engineering, and other specific applications, the physical and mechanical properties

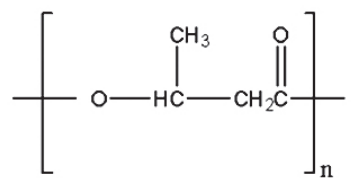

Fig. 1. Chemical structure of poly(3-hydroxybutyrate) (PHB). 
of PHB need to be diversified and improved. The main limitation, besides its relatively high cost of production, is the lack of bioactivity $(12,16)$. In addition, hydrophobic PHB needs to have a hydrophilic character for biomedical applications (2). Porosity, surface properties and, in part, mechanical strength are determined by processing conditions when preparing a scaffold for bone tissue engineering (4). PHB, like all PHAs, is sensitive to processing conditions, especially to temperature and shear and exhibits a very narrow processing window (12). For example, PHBs of low molecular mass $\left(<1 \times 10^{3}\right)$ are characterized by early thermal degradation, near their melting temperature (above $\left.180{ }^{\circ} \mathrm{C}\right)(12,18)$. Additives, blends and composites are mostly used to overcome these problems (8). Furthermore, PHB is soluble in few solvents, i.e., chloroform, dichloromethane and dimethyl formamide; therefore, the formation of composite structures is challenging (19). As already mentioned, thermal molding is also difficult, since above $150{ }^{\circ} \mathrm{C}$ most of the PHA-based polymers break down to fatally toxic trans-crotonic acids. Taken together, PHB limitations such as mechanical properties, high production cost, limited functionalities, incompatibility with conventional thermal processing techniques, susceptibility to thermal degradation have limited effective application of $\mathrm{PHB}$ and these are still challenges to be addressed in the future. In the present review, we report on the current biomedical applications of PHB in bone tissue engineering with the emphasis on physicochemical modifications of PHB and in vitro and in vivo experiments.

\section{BIOMEDICAL APPLICATIONS OF PHB IN BONE TISSUE ENGINEERING}

\section{Physicochemical modifications of PHB in the field of bone tissue engineering}

Numerous studies investigate the use of PHB in bone tissue engineering (20). Bone tissue engineering is a research area where bone replacements are being developed and clinically tested in cases of orthopedic defects, bone tumors, and in maxillofacial, neck and head surgery (11). It provides solutions for generating new bone tissue with good functional and mechanical qualities (21). Recent work in this field has been focused on the development of three-dimensional porous scaffolds loaded with specific living cells to provide tissue regeneration in a natural way. According to Hutmacher (22), a scaffold should satisfy the following criteria: (i) to be bioresorbable and biocompatible with a controllable degradation and resorption rate to match cell/tissue growth in vitro/vivo; (ii) to have suitable surface chemistry for cell attachment, proliferation and differentiation; (iii) to be three-dimensional and highly porous to enable cell growth, flow transport of nutrients and metabolic waste; (iv) to have proper mechanical properties like the tissue at the site of implantation. In addition to being biocompatible and biodegradable, PHB-based biomaterials are piezoelectric and thus may promote bone growth in vivo (23). PHB has the disadvantages of having low compressive modulus and poor bioactivity. Ceramic implants, on the other side, are stiffer but they are often fragile and known to fracture during clinical use (24). Therefore, a combination of PHB with a bioactive ceramic is expected to improve the mechanical and chemical properties of composites (24).

Bone is considered to be a composite material consisting of nanosized calcium phosphates $(\mathrm{CaP})$ embedded in a collagen-rich organic matrix permeated with pores filled with liquids (24). Most similar to the mineral part of the bone is hydroxyapatite $\left[\mathrm{Ca}_{10}\left(\mathrm{PO}_{4}\right)_{6}(\mathrm{OH})_{2}\right.$, HA] (24). Its chemical similarity to the inorganic bone materials makes it biocompatible, 
modifiable by the osteoclasts and slowly biodegrading in situ $(25,26)$. As HA is a porous material, ingrowth of capillaries and other vessels is possible (27). In this way, the cells in the scaffold are supplied with metabolic oxygen and nutrients. Wang et al. (28) showed that growth and alkaline phosphatase activity of osteoblasts were better on PHB-HA scaffolds compared to PHB scaffolds. According to Hayati et al. (11), $15 \%(\mathrm{~m} / \mathrm{m})$ of HA nanoparticles was the best content for incorporation of HA in a PHB matrix, while Shishatskaya et al. (29) obtained the best results for growth and differentiation of osteoblasts on PHB/HA composites containing 10 and $20 \%$ HA. Sadat-Shojai et al. (24) have proven that $15 \%(\mathrm{~m} / \mathrm{m})$ of HA nanoparticles stimulate cell proliferation and cell differentiation. HA nanoparticles covering the PHB fiber surface enhanced differentiation of mesenchymal stromal cells toward the osteoblast phenotype (30-32). Titanium oxide $\left(\mathrm{TiO}_{2}\right)$ showed no effect on osteoblast growth when $\mathrm{TiO}_{2}$ was added to $\mathrm{PHB} / \mathrm{HA}$ scaffolds (34). The above mentioned studies also reported improved mechanical properties of PHB/HA scaffolds $(3,11,24,32)$. Bioglass with osteoconduction and osteostimulation properties is another bioactive inorganic phase used in making composites with PHB. It has been shown that optimal concentration of nanobioglass $(7.5 \%, \mathrm{~m} / \mathrm{m})$ in nanocomposite scaffolds significantly improves cell proliferation and induces better cytocompatibility and osteoconductivity compared to PHB scaffolds (35). Bioactivity of PHB composites with bioglass $(10 \%, \mathrm{~m} / \mathrm{m})$ was also proven by Misra et al. (36). Nanobioglass was shown to improve mechanical strength and increase the scaffold degradation kinetics $(35,36)$. The latest study evaluated the response of bone to novel biodegradable polymeric composite implants made of $\mathrm{PHB}$ and $\mathrm{Herafill}^{\circledR}$ (37). Herafill ${ }^{\circledR}$ is a composite made of calcium sulfate $\left(\mathrm{CaSO}_{4}\right)$, calcium carbonate $\left(\mathrm{CaCO}_{3}\right)$ and glycerol tripalmitate (37). It was clinically used as an alternative bone substitute material with proven osteoconductivity (38). The highest value of bone accumulation was observed around the implant of the PHB composite with $30 \%$ of Herafill ${ }^{\circledR}$; however, the authors could not give any clear recommendation regarding the use of PHB composite materials as biodegradable implants for bone fixation (37). As a natural polysaccharide, chitosan is known for its biocompatibility and therefore PHB/HA/chitosan composite scaffolds (39) and $\mathrm{PHB} /$ biophasic calcium phosphate/chitosan membranes $(40,41)$ were tested for their use in bone tissue engineering. Chitosan reduced crystallinity and improved surface properties and biological activity of scaffolds $(3,20,39)$. Most recent studies report modifications of PHB with poly( $\varepsilon$-caprolactone) (PCL) and sol-gel silica (42), PCL and bioglass (43), cellulose acetate (44), zwitterionic poly(4-vinylpiridine) hydrophilic groups on poly(octadecylacrylate) blocks (45) and natural anionic polysaccharides (46). Sol-gel silica enhanced the stiffness and strength of PHB/PCL fibers (42), while PHB/cellulose acetate scaffolds had three times higher degradation rates compared to PHB scaffolds (44). Incorporation of natural anionic polysaccharides into PHB decreased its crystallinity, enhanced surface hydrophilicity, reduced brittleness and enhanced degradation of polymer blend films (46). All five studies have proven cell growth and proliferation on those scaffolds; nevertheless, further research is needed. Physicochemical modifications of PHB are presented in Table I.

\section{In vitro biocompatibility of PHB on bone cells}

In vitro tests of $\mathrm{PHB}$ and $\mathrm{PHB}$ composite scaffolds were performed with osteoblasts of different organisms (16). Polymeric materials, bone cell types and methods of analysis of biocompatibility tests in vitro are reported in Table II. Wang et al. $(28,48)$ evaluated the 
Table I. Physicochemical modifications of PHB in the field of bone tissue engineering

\begin{tabular}{|c|c|c|c|c|}
\hline Modifier & $\begin{array}{l}\text { Concentration in } \\
\text { PHB }(\%, m / m)\end{array}$ & Porosity (\%) & $\begin{array}{l}\text { Enhanced } \\
\text { properties }\end{array}$ & Reference \\
\hline \multirow{8}{*}{ HA } & 10 & Solid film & \multirow{8}{*}{ Bioactivity } & 28 \\
\hline & $10-20$ & Solid film & & 29 \\
\hline & 15 & 77 & & 11 \\
\hline & 15 & Solid film & & 24 \\
\hline & 20 & 71(blend)/83(spray) & & 30 \\
\hline & 10 & 84 & & 31 \\
\hline & 5 & 82 & & 32 \\
\hline & 15 & Not reported & & 33 \\
\hline $\mathrm{HA} / \mathrm{TiO}_{2}$ & 50 & 76 & Cell binding & 34 \\
\hline Herafill $^{\circledast}$ & 30 & Solid film & Bioactivity & 37 \\
\hline \multirow{2}{*}{ Bioglass } & 7.5 & 80 & Bioactivity & 35 \\
\hline & 10 & 85 & Bioactivity & 36 \\
\hline $\mathrm{CP} /$ chitosan & $3 / 10$ & 41 & Bioactivity & 40 \\
\hline $\mathrm{CP} /$ chitosan & 50 & Not reported & Bioactivity & 41 \\
\hline PCL/silica & Not reported & Not reported & Bioactivity & 42 \\
\hline PCL/bioglass & 5 & Not reported & Bioactivity & 43 \\
\hline $\mathrm{CA}$ & $10,20,30,40$ & $86-81$ & Cytocompatibility & 44 \\
\hline 4VP-r-ODA & Not reported & 36 & Bioactivity & 45 \\
\hline $\begin{array}{l}\text { Natural anionic } \\
\text { polysaccharides }\end{array}$ & $5,10,20,30,50$ & Not reported & Bioactivity & 46 \\
\hline $\begin{array}{l}\text { Magnesium discs } \\
\text { with PHB coating }\end{array}$ & - & Not reported & Bioactivity & 47 \\
\hline
\end{tabular}

CA - cellulose acetate, CP - calcium phosphate, PCL - poly( $\varepsilon$-caprolactone), 4VP-r-ODA - zwitterionic poly(4-vinylpiridine) hydrophilic groups on poly(octadecylacrylate) blocks

attachment, proliferation and differentiation of rabbit bone marrow cells on PHB and PHBHA scaffolds. PHB-HA scaffolds were shown to be a suitable biomaterial for rabbit bone marrow cell attachment, proliferation and differentiation $(28,32,48)$. Several studies established in vitro tests of PHB scaffolds on murine osteoblasts $(6,7,29)$. Sadat-Shojai et al. $(24)$ showed a significant increase in proliferation and differentiation of murine osteoblasts on PHB/HA composites. A novel study by Zhijiang et al. (44) demonstrated that the PHB/cellulose acetate blend nanofiber scaffolds have better biocompatibility and higher proliferation rate of murine osteoblasts than a pure PHB film. In their recent studies, Sadat-Shojai et al. describe a new strategy for fabrication of bone scaffolds using electrospun nano-HA/ PHB fibers (33) and electrospun nano-HA/PHB and protein gels (49). According to their results, mechanical properties of the construct were good and murine osteoblasts inside the scaffolds were viable. Since cells rapidly proliferate on PHB scaffolds, Peng et al. (50) 
Table II. Polymeric materials, bone cell types and methods of analysis of biocompatibility tests in vitro

\begin{tabular}{|c|c|c|c|}
\hline Polymeric material & Bone cell type & Methods of analysis & Reference \\
\hline PHB scaffolds & Rabbit bone marrow cells & $\begin{array}{l}\text { SEM analysis } \\
\text { MTT assay } \\
\text { ALP assay }\end{array}$ & 48 \\
\hline PHB/HA scaffolds & Rabbit bone marrow cells & $\begin{array}{l}\text { SEM analysis } \\
\text { MTT assay } \\
\text { ALP assay }\end{array}$ & 28 \\
\hline PHB/HA scaffolds & Rabbit bone marrow cells & $\begin{array}{l}\text { SEM analysis } \\
\text { MTT assay } \\
\text { ALP assay } \\
\text { RT-PCR }\end{array}$ & 32 \\
\hline PHB/HA composites & Murine osteoblasts & $\begin{array}{l}\text { SEM analysis } \\
\text { MTT assay }\end{array}$ & 29 \\
\hline $\begin{array}{l}\text { PHB and poly( } \varepsilon \text {-caprolactone) } \\
\text { copolymers }\end{array}$ & $\begin{array}{l}\text { Murine osteoblasts } \\
\text { (MC3T3-E1) }\end{array}$ & $\begin{array}{l}\text { SEM analysis } \\
\text { MTT assay }\end{array}$ & 6 \\
\hline $\begin{array}{l}\text { PHB scaffolds coated with } \\
\text { collagen I and chondroitin } \\
\text { sulfate }\end{array}$ & $\begin{array}{l}\text { Human mesenchymal } \\
\text { stem cells (hMSCs) }\end{array}$ & $\begin{array}{l}\text { SEM analysis } \\
\text { ALP assay }\end{array}$ & 52 \\
\hline PBS/bioglass scaffolds & $\begin{array}{l}\text { Human osteosarcoma cell } \\
\text { line (MG-63) }\end{array}$ & $\begin{array}{c}\text { SEM analysis } \\
\text { Alamar blue assay }\end{array}$ & 36 \\
\hline PHB films & Rat osteoblasts & $\begin{array}{c}\text { SEM analysis } \\
\text { BrdU incorporation } \\
\text { Flow cytometry } \\
\text { qRT-PCR }\end{array}$ & 50 \\
\hline PHB scaffolds & $\begin{array}{c}\text { Mouse mesenchymal stem } \\
\text { cells (mMSCs) }\end{array}$ & $\begin{array}{l}\text { SEM analysis } \\
\text { MTS assay }\end{array}$ & 7 \\
\hline PHB/bioglass scaffolds & $\begin{array}{l}\text { Human osteosarcoma cell } \\
\text { line (MG-63) }\end{array}$ & $\begin{array}{c}\text { SEM analysis } \\
\text { MTT assay } \\
\text { Trypan blue staining } \\
\text { ALP assay }\end{array}$ & 35 \\
\hline PHB/HA scaffolds & $\begin{array}{l}\text { Human osteosarcoma cell } \\
\text { line (MG-63) }\end{array}$ & $\begin{array}{l}\text { SEM analysis } \\
\text { MTT assay }\end{array}$ & 11 \\
\hline PHB/HA scaffolds & $\begin{array}{c}\text { Human osteosarcoma cell } \\
\text { line (MG-63) }\end{array}$ & $\begin{array}{l}\text { SEM analysis } \\
\text { MTT assay } \\
\text { ALP assay }\end{array}$ & 31 \\
\hline
\end{tabular}




\begin{tabular}{|c|c|c|c|}
\hline Polymeric material & Bone cell type & Methods of analysis & Reference \\
\hline $\begin{array}{l}\text { PHB/HA } \\
\text { scaffolds }\end{array}$ & $\begin{array}{l}\text { Murine osteoblasts } \\
\text { (MC3T3-E1) }\end{array}$ & $\begin{array}{c}\text { SEM analysis } \\
\text { Calcein-AM/EthD-1 } \\
\text { live/dead kit } \\
\text { Alamar blue assay } \\
\text { DNA quantification } \\
\text { Phalloidin assay } \\
\text { Alizarin red staining } \\
\text { ALP assay }\end{array}$ & 24 \\
\hline PHB/bioactive glass filler & Human bone marrow cells & $\begin{array}{c}\text { SEM analysis } \\
\text { MTT assay } \\
\text { ALP assay } \\
\text { Phalloidin assay }\end{array}$ & 23 \\
\hline PHB/HA scaffolds & $\begin{array}{l}\text { Human mesenchymal } \\
\text { stromal cells (hMSCs) }\end{array}$ & $\begin{array}{c}\text { SEM analysis } \\
\text { MTS assay } \\
\text { ALP assay } \\
\text { Alizarin red staining }\end{array}$ & 30 \\
\hline $\begin{array}{l}\text { PHB and biphasic calcium } \\
\text { phosphate/chitosan } \\
\text { membranes }\end{array}$ & Rat osteoblasts & MTS assay & 40 \\
\hline $\begin{array}{c}\text { PHB membranes designed by } \\
\text { NaOH based alkaline } \\
\text { treatment }\end{array}$ & Human osteoblasts & $\begin{array}{l}\text { SEM analysis } \\
\text { MTT assay }\end{array}$ & 54 \\
\hline $\begin{array}{l}\text { PHB/PCL/silica } \\
\text { scaffolds }\end{array}$ & $\begin{array}{c}\text { Human osteosarcoma cell } \\
\text { line (MG-63) }\end{array}$ & $\begin{array}{l}\text { SEM analysis } \\
\text { Phalloidin assay } \\
\text { CCK-8 assay } \\
\text { ALP assay }\end{array}$ & 42 \\
\hline PHB/HA scaffolds & $\begin{array}{l}\text { Human adipose-derived } \\
\text { stem cells (HADSCs) } \\
\text { co-cultured with human } \\
\text { osteoblasts (HOB) }\end{array}$ & $\begin{array}{c}\text { SEM analysis } \\
\text { Alamar blue assay } \\
\text { ALP assay } \\
\text { Alizarin red staining } \\
\text { qRT-PCR }\end{array}$ & 55 \\
\hline $\mathrm{PHB} / \mathrm{HA} / \mathrm{TiO}_{2}$ scaffolds & Human osteoblast cell line & $\begin{array}{l}\text { SEM analysis } \\
\text { MTT assay }\end{array}$ & 34 \\
\hline PHB/cellulose acetate scaffolds & Murine fibroblasts (3T3) & $\begin{array}{l}\text { SEM analysis } \\
\text { MTT assay }\end{array}$ & 44 \\
\hline $\begin{array}{l}\text { Magnesium disks with PHB } \\
\text { coating }\end{array}$ & $\begin{array}{l}\text { Murine osteoblasts } \\
\text { (MC3T3-E1) }\end{array}$ & $\begin{array}{l}\text { SEM analysis } \\
\text { MTT assay }\end{array}$ & 47 \\
\hline
\end{tabular}




\begin{tabular}{|c|c|c|c|}
\hline Polymeric material & Bone cell type & Methods of analysis & Reference \\
\hline $\begin{array}{l}\text { PHB/chitosan/ calcium } \\
\text { phosphate films }\end{array}$ & $\begin{array}{l}\text { Murine osteoblasts } \\
\text { (MC3T3-E1) }\end{array}$ & $\begin{array}{l}\text { SEM analysis } \\
\text { MTS assay } \\
\text { ALP assay }\end{array}$ & 41 \\
\hline PHB/HA nanohybrids & $\begin{array}{l}\text { Murine osteoblasts } \\
\text { (MC3T3-E1) }\end{array}$ & $\begin{array}{c}\text { SEM analysis } \\
\text { Calcein-AM/EthD-1 } \\
\text { live/dead kit } \\
\text { ALP assay } \\
\text { Alamar blue assay } \\
\text { Phalloidin assay } \\
\text { DAPI staining }\end{array}$ & 33 \\
\hline $\begin{array}{c}\text { PHB/HA scaffolds with protein } \\
\text { hydrogel }\end{array}$ & $\begin{array}{l}\text { Murine osteoblasts } \\
\text { (MC3T3-E1) }\end{array}$ & $\begin{array}{c}\text { SEM analysis } \\
\text { Calcein-AM/EthD-1 } \\
\text { live/dead kit } \\
\text { Alamar blue assay } \\
\text { DNA quantification } \\
\text { Phalloidin assay } \\
\text { ALP assay }\end{array}$ & 49 \\
\hline $\begin{array}{l}\text { PHB/PCL/bioglass } \\
\text { scaffolds }\end{array}$ & $\begin{array}{c}\text { Human osteosarcoma cell } \\
\text { line (MG-63) }\end{array}$ & $\begin{array}{c}\text { SEM analysis } \\
\text { CCK-8 assay } \\
\text { ALP assay } \\
\text { Alizarin red staining }\end{array}$ & 43 \\
\hline $\begin{array}{c}\text { PHB surface treated by } \mathrm{KrF} \\
\text { laser }\end{array}$ & $\begin{array}{l}\text { Human osteosarcoma } \\
\text { (U-2 OS) }\end{array}$ & $\begin{array}{l}\text { SEM analysis } \\
\text { Phalloidin assay } \\
\text { DAPI staining }\end{array}$ & 56 \\
\hline
\end{tabular}

Alamar blue assay - quantifying the metabolic activity; Alizarin red staining - in vitro calcium containing deposits and mineralized matrix analysis; ALP assay - alkaline phosphatase activity assay; BrdU incorporation - staining of 5-bromodeoxyuridine, evaluation of cell proliferation; Calcein-AM/EthD-1 live/dead kit - calcein-AM/ethidium homodimer-1, visualization of cell viability; CCK-8 - cell counting kit-8; DAPI - 4',6-diamidino-2-phenylindole; DNA quantification - determination of cell proliferation; ECM - extracellular matrix; ELISA - enzyme-linked immunosorbent assay; MTT assay - 3-(4,5-dimethylthiazol-2yl)-2,5-diphenyltetrazolium bromide, in vitro mitochondrial metabolic activity test; MTS assay - 3-(4,5-dimethylthiazol-2-yl)-5(3-carboxymethophenyl)-2(4sulfofenyl)-2H-tetrazolium, in vitro cells viability test; Phalloidin assay - in vitro immunofluorescence analysis; qRT-PCR - quantitative real-time-polymerase chain reaction, in vitro gene expression test; SEM - scanning electron microscopy; Trypan blue staining - quantification of viable cells

tested the risk of carcinogenicity. Their results confirmed no tumor induction when proliferating rat osteoblasts were grown on PHB films. Another study on fibroblasts has proven that PHB is not genotoxic and did not alter the expression of the proto-oncogenes and anti-apoptotic genes analyzed in the study (51). Wang et al. (52) proved proliferation of rat osteoblasts on various PHA films; however, the lowest percentage of apoptotic cells was seen when cells were grown on PHB. Tai et al. (40) developed asymmetric membranes of 
Table III. Polymeric materials and places of PHB implantations in animal bone

\begin{tabular}{ccc}
\hline Polymeric material & Place of implantation & Reference \\
\hline PHB patches & Anterior skull base of minipigs & 57 \\
\hline PHB/HA composites & Cat femur & 59 \\
\hline $\begin{array}{c}\text { PHB composites with zirconium } \\
\text { dioxide and crystalline Mg }\end{array}$ & Rat femur & 60 \\
\hline PHB patches & $\begin{array}{c}\text { Surgically created defects on male rats' } \\
\text { cranium }\end{array}$ & 58 \\
\hline $\begin{array}{c}\text { PHB composites with zirconium } \\
\text { dioxide and Herafill }\end{array}$ & Growing rats' femur & 37 \\
\hline
\end{tabular}

PHB and biphasic calcium phosphate/chitosan and showed increased proliferation of rat primary osteoblasts on membranes. When $\mathrm{PHB} /$ calcium phosphate/chitosan composite films were enzymatically degraded, significant proliferation of murine osteoblasts was observed (41).

Since PHB is a candidate for use in human bone engineering, numerous studies are aimed at assessing biocompatibility using human osteoblasts. Hayati et al. (11) and Saadat et al. (31) confirmed the biocompatibility of PHB/HA composite scaffolds using the human osteosarcoma cell line (MG-63). Morphology of the attached MG-63 cells in direct contact with the scaffolds demonstrated appropriate cell-scaffold interaction. Similar results on the appropriate cell-scaffold interaction were obtained when MG-63 cells were grown on PHB composite scaffolds with bioglass nanoparticles $(35,36)$. MG-63 cells showed good osteoblastic differentiation on both PHB/PCL/sol-gel derived silica hybrid scaffolds (42) as well as on PHB/PCL/bioglass hybrid scaffolds (43). Differentiation of human bone marrow cells toward osteoblasts was studied and proven on novel acrylic bone cement combining PHB and bioactive glass (23). Ramier et al. (30) developed different types of PHB-based nanofibrous scaffolds and tested them with human mesenchymal stromal cells (hMSCs). Faster cell development was recorded on gelatin-containing scaffolds, whereas HA nanoparticles covering the scaffold surface enhanced differentiation of hMSCs towards the osteoblast phenotype. Rentsch et al. (53) seeded hMSCs on PHB scaffolds coated with extracellular matrix components type I collagen and chondroitin sulfate. Their study demonstrated the positive effect of collagen I and chondroitin sulfate on proliferation and differentiation of hMSCs. Karahaliloğlu et al. (54) used a NaOH-based alkaline treatment to create PHB membranes and proved increased proliferation of human osteoblasts on the $\mathrm{NaOH}$-treated PHB membranes. Furthermore, $\mathrm{NaOH}$-treated PHB surfaces inhibited Staphylococcus aureus growth compared to the untreated PHB surface. Pourmollaabbassi et al. (34) evaluated the growth and adhesion of human osteoblasts on $\mathrm{PHB} / \mathrm{HA} / \mathrm{TiO}_{2}$ scaffolds. They observed no effect of $\mathrm{TiO}_{2}$ on cell growth and, therefore, concluded that HA alone affected the growth and cell osteoblast adhesion on the scaffold. A novel study by Rozila et al. (55) evaluated the osteogenic potential of human adipose-derived stem cells (HADSCs) when co-cultured with human osteoblasts (HOBs) on electrospun PHB/HA scaffolds. The highest alkaline phosphatase (ALP) production and calcium deposition were shown in the monoculture of $\mathrm{HOBs}$ on $\mathrm{PHB} / \mathrm{HA}$ scaffolds. Nevertheless, co-culture 
of HADSCs/HOBs 1:1 on PHB/HA scaffold showed significantly higher cell proliferation, production of ALP, extracellular mineralization and osteogenic-related gene expression compared to other tested groups. The authors concluded that the good interaction of HADSCs and HOBs enhanced the differentiation of stem cells. However, osteogenesis is promoted not only by cell-cell contacts, but also by the bioactive composition of the PHB/ HA-based scaffold (55). In the latest study, the growth of human osteosarcoma cells was determined after PHB surface was treated with a $\mathrm{KrF}$ laser (56). The proposed method was shown to be suitable for certain modifications in surface properties of the PHB scaffold.

\section{In vivo studies of $P H B$ in bone}

The following level in evaluating biocompatibility of polymer scaffolds is to observe the response when they are implanted into tissue (Table III).

Bernd et al. (57) used PHB patches to cover anterior skull base defects in minipigs. The results showed increasing closure of bone defect with time. After 9 months, the anterior skull base defect was completely closed. Analysis of biodegradation detected a continuous breakdown of PHB. Gredes et al. (58) studied PHB patches after implantation in surgically created defects on the cranium of adult rats. No sign of cellular inflammation or PHB rejection was detected. Twelve weeks after surgery, bone formation was proven in all PHBtreated cavities. Furthermore, a pronounced development of blood vessels was observed. However, the authors suggested that the osteoinductive properties of PHB should be further analyzed (58). On the other hand, Alves et al. (59) observed a chronic local inflammatory response when $\mathrm{PHB} / \mathrm{HA}$ composites were implanted in cats. Brigham and Sinskey (16) summarized early in vivo biocompatibility studies of different PHA matrices and showed that post-traumatic inflammation following surgical procedures was common around PHA implants. Celarek et al. (60) designed a study to evaluate PHB composites with zirconium dioxide, crystalline magnesium alloys and $\mathrm{MgZnCa}$ bulk metallic glasses as possible candidates for bone implants. PHB composites were implanted in rats' femora. According to the authors, mechanical properties and degradation of studied materials were unsatisfactory. Meischel et al. (37) evaluated the response of bone to PHB composite implants in the femora of growing rats. PHB composites were made with zirconium dioxide and Herafill ${ }^{\circledR}$. After 36 weeks in vivo, no significant degradation in any of the implants was found. Composites containing Herafill ${ }^{\circledR}$ were the most attractive for bone cells with regard to accumulation and growth of bone cells.

As shown above, the results obtained by the in vivo studies demonstrated that the PHB-based systems are promising candidates for bone repair. Unfortunately, only few examples of in vivo studies involving PHB and PHB scaffolds are present in the literature $(37,57-60)$. Therefore, more research is needed to confirm and validate the possibility of using this polymer in biomedicine.

\section{CONCLUSIONS AND OUTLOOK}

The field of bone tissue engineering has progressed rapidly over the past years. Use of natural polymers seems promising in the bone regeneration process. PHB is a bacterially derived polymer known to be biocompatible and biodegradable. Due to its poor mechanical properties, PHB needs to be modified in order to be useful in biomedical applica- 
tions. Different physicochemical modifications of PHB in the field of bone tissue engineering are proposed to improve the PHB properties. Most commonly used modifiers are HA, bioglass and chitosan in combination with calcium phosphate. All three modifiers improved mechanical properties of tested scaffolds compared to neat PHB. Furthermore, the use of HA, bioglass, cellulose acetate or natural anionic polysaccharides as PHB modifiers decreased the degradation rate of tested scaffolds. Enhanced bioactivity is a common feature of all modifiers reported in this review. On the other hand, mechanical properties of human bones vary depending on the species, race, sex and age. Regional variation in mechanical properties is also observed within the same body. Therefore, scaffolds will need to be fabricated accordingly to match the mechanical properties of each respective application. To our knowledge, no study has compared the mechanical properties, osteoinductivity and biodegradability of PHB composites when implanted in male and female test animals yet.

Biocompatibility evaluations conducted under different experimental conditions and using various cell lines highlighted the good in vitro and in vivo biocompatibility of PHB and PHB composites. Furthermore, PHB/HA composites were proven to enable differentiation of human stem cells toward osteoblast phenotype. Thus, the conclusion was made that $\mathrm{PHB} / \mathrm{HA}$ scaffolds promote osteogenesis. Studies proved HA to be the optimal modifier for $\mathrm{PHB}$, since PHB/HA scaffolds were shown to have good mechanical properties, optimal osteoinductivity, suitable porosity and, finally, the desired rate of degradability. In vivo studies showed new bone formation around PHB patches but slow degradation of PHB implants. Sufficient vascularization of implants would certainly improve cell growth and enable faster degradation of biomaterial. Nevertheless, vascularization in vivo is dependent on scaffold structure, namely, pore size and interconnectivity of pores. Also, local delivery of angiogenic growth factors would accelerate vascularization of an implanted graft. Angiogenic growth factors may also be incorporated into the scaffold. The major limitation of in vivo results is the small number of such studies; therefore, further research is needed. To our knowledge, PHB has not received approval for uses in biomedicine either by the European Medicines Agency, the Food and Drug Administration or Japanese Pharmaceuticals and Medical Devices Agency; therefore, no clinical trials have been carried out to date.

Although many promising results have been achieved, further research needs to be carried out before PHB and PHB composites can be commercialized for biomedical applications. Challenges for the future are cost reduction of the production and extraction of PHB, optimization of PHB regarding all requirements for bone tissue engineering scaffolds and, finally, in vivo studies to confirm the usability of PHB composites for bone tissue engineering.

\section{REFERENCES}

1. H. Tian, Z. Tang, X. Zhuang, X. Chen and X. Jing, Biodegradable synthetic polymers: Preparation, functionalization and biomedical application, Prog. Polym. Sci. 37 (2012) 237-280; https://doi.org/ 10.1016/j.progpolymsci.2011.06.004

2. D. B. Hazer, E. Kiliçay and B. Hazer, Poly(3-hydroxyalkanoate)s: Diversification and biomedical applications A state of art review, Mater. Sci. Eng. C 32 (2012) 637-647; https://doi.org/10.1016/j. msec.2012.01.021 
3. M. Goonoo, A. Bhaw-Luximon, P. Passanha, S. R. Esteves and D. Jhurry, Third generation poly(hydroxyacid) composite scaffolds for tissue reengineering, J. Biomed. Mater. Res. B Appl. Biomater. 105B (2017) 1667-1684; https://doi.org/ 10.1002/jbm.b.33674

4. A. R. Amini, C. T. Laurencin and S. P. Nukavarapu, Bone tissue engineering: recent advances and challenges, Crit. Rev. Biomed. Eng. 40 (2012) 363-408.

5. S. Bose, M. Roy and A. Bandyopadhyay, Recent advances in bone tissue engineering scaffolds, Trends Biotechnol. 30 (2012) 546-554; https://doi.org/10.1016/j.tibtech.2012.07.005

6. L. Wu, L. Wang, X. Wang and K. Xu, Synthesis, characterization and biocompatibility of novel biodegradable star block copolymers based on poly[(R)-3-hydroxybutyrate] and poly(E-caprolactone), Acta Biomater. 6 (2010) 1079-1089; https://doi.org/10.1016/j.actbio.2009.08.014

7. E. Masaeli, M. Morshed, P. Rasekhian, S. Karbasi, K. Karbalaie, F. Karamali, D. Abedi, S. Razavi, A. Jafarian-Dehkordi, M. H. Nasr-Esfahani and H. Baharvand, Does the tissue engineering architecture of Poly(3-hydroxybutyrate) scaffolds affect cell-material interactions? J. Biomed. Mater. Res. A 100A (2012) 1907-1918; https://doi.org/10.1002/jbm.a.34131

8. M. M. Reddy, S. Vivekanandhan, M. Misra, S. K. Bhatia and A. K. Mohanty, Biobased plastics and bionanocomposites: Current status and future opportunities, Prog. Polym. Sci. 38 (2013) 1653-1689; https://doi.org/10.1016/j.progpolymsci.2013.05.006

9. C. Peña, T. Castillo, A. Garcia, M. Millan and D. Segura, Biotechnological strategies to improve production of microbial poly(3-hydroxybutyrate): a review of recent research work, Microbial Biotechnol. 7 (2014) 278-293; https://doi.org/10.1111/1751-7915.12129

10. S. Centeno-Leija, G. Huerta-Beristain, M. Giles-Gomez, F. Bolivar, G. Gosset and A. Martinez, Improving poly-3-hydroxybutyrate production in Escherichia coli by combining the increase in the NADPH pool and acetyl-CoA availability, Antonie van Leeuwenhoek 105 (2014) 687-696; https://doi. org/10.1007/s10482-014-0124-5

11. A. M. Hayati, S. M. Hosseinalipour, H. R. Rezaie and M. A. Shokrgozar, Characterization of poly(3hydroxybutyrate)/nano-hydroxyapatite composite scaffolds fabricated without the use of organic solvents for bone tissue engineering applications, Mater. Sci. Eng. C 32 (2012) 416-422; https://doi. org/10.1016/j.msec.2011.11.013

12. B. S. Kushwah, A. V.S. Kushwah and V. Singh, Towards understanding polyhydroxyalkanoates and their use, J. Polym. Res. 23 (2016) 153-166; https://doi.org/10.1007/s10965-016-0988-3

13. R. W. Lenz and R. H. Marchessault, Bacterial polyesters: Biosynthesis, biodegradable plastics and biotechnology, Biomacromolecules 6 (2005) 1-8; https://doi.org/10.1021/bm049700c

14. Y. Zhao, B. Zou, Z. Shi, Q. Wu and G. Q. Chen, The effect of 3-hydroxybutyrate on the in vitro differentiation of murine osteoblast MC3T3-E1 and in vivo bone formation in ovariectomized rats, Biomaterials 28 (2007) 3063-3073; https://doi.org/10.1016/j.biomaterials.2007.03.003

15. S. Cheng, G. Q. Chen, M. Leski, B. Zou, Y. Wang and Q. Wu, The effect of D,L- $\beta$-hydroxybutyric acid on cell death and proliferation, Biomaterials 27 (2006) 3758-3765; https://doi.org/10.1016/j.biomaterials.2006.02.046

16. C. J. Brigham and A. J. Sinskey, Applications of polyhydroxyalkanoates in the medical industry, Int. J. Biotechnol. Wellness Ind. (IJBWI) 1 (2012) 53-60

17. E. I. Shishatskaya and T. G. Volova, A comparative investigation of biodegradable polyhydroxyalkanoate films as matrices for in vitro cell cultures, J. Mater. Sci. Mater. Med. 15 (2004) 915-923; https://doi.org/10.1023/B:JMSM.0000036280.98763.c1

18. S. W. Hong, H. W. Hsu and M. T. Ye, Thermal properties and applications of low molecular weight polyhydroxybutyrate, J. Therm. Anal. Calorim. 111 (2013) 1243-1250; https://doi.org/10.1007/s10973012-2503-3

19. I. Manavitehrani, A. Fathi, H. Badr, S. Daly, A. N. Shirazi and F. Dehghani, Biomedical applications of biodegradable polyesters, Polymers 8 (2016) Article ID 20 (32 pages); https://doi.org/10.3390/ polym 8010020 
20. R. Y. Basha, S. Kumar and M. Doble, Design of biocomposite materials for bone tissue regeneration, Mater. Sci. Eng. C 57 (2015) 452-463; https://doi.org/10.1016/j.msec.2015.07.016

21. S. H. Lee and H. Shin, Matrices and scaffolds for delivery of bioactive molecules in bone and cartilage tissue engineering, Adv. Drug Deliv. Rev. 59 (2007) 339-359; https://doi.org/10.1016/j.addr.2007.03.016

22. D. W. Hutmacher, Scaffolds in tissue engineering bone and cartilage, Biomaterials 21 (2000) 25292543; https://doi.org/10.1016/S0142-9612(00)00121-6

23. P. P. Lopes, M. P. Garcia, M. H. Fernandes and M. H. V. Fernandes, Acrylic formulations containing bioactive and biodegradable filters to be used as bone cements: Properties and biocompatibility assessment, Mater. Sci. Eng. C 33 (2013) 1289-1299; https://doi.org/10.1016/j.msec.2012.12.028

24. M. Sadat-Shojai, M. T. Khorasani, A. Jamshidi and S. Irani, Nano-hydroxyapatite reinforced polyhydroxybutyrate composites: A comprehensive study on the structural and in vivo biological properties, Mater. Sci. Eng. C 33 (2013) 2776-2787; https://doi.org/10.1016/j.msec.2013.02.041

25. Y. Zhang, L. Hao, M. M. Savalani, R. A. Harris, L. Di Silvio and K. E. Tanner, In vitro biocompatibility of hydroxyapatite-reinforced polymeric composites manufactured by selective laser sintering, J. Biomed. Mater. Res. A 91A (2009) 1018-1027; https://doi.org/10.1002/jbm.a.32298

26. H. Zhou and J. Lee, Nanoscale hydroxyapatite particles for bone tissue engineering, Acta Biomater. 7 (2011) 2769-2781; https://doi.org/10.1016/j.actbio.2011.03.019

27. J. Michel, M. Penna, J. Kochen and H. Cheung, Recent advances in hydroxyapatite scaffolds containing mesenchymal stem cells, Stem Cell. Int. 2015 (2015) Article ID 305217 (13 pages); https://doi. org/10.1155/2015/305217

28. Y. W. Wang, Q. Wu, J. Chen and G. Q. Chen, Evaluation of three-dimensional scaffolds made of blends of hydroxyapatite and poly(3-hydroxybutyrate-co-3-hydroxyhexynoate) for bone reconstruction, Biomaterials 26 (2005) 899-904; https://doi.org/10.1016/j.biomaterials.2004.03.035

29. E. I. Shishatskaya, I. A. Khlusov and T. G. Volova, A hybrid PHB-hydroxyapatite composite for biomedical application: production, in vitro and in vivo investigation, J. Biomater. Sci. Polym. Ed. 17 (2006) 481-498.

30. J. Ramier, D. Grande, T. Bouderlique, O. Stoilova, N. Manolova, I. Rashkov, V. Langlois, P. Albanese and E. Renard, From design of bio-based biocomposite electrospun scaffolds to osteogenic differentiation of human mesenchymal stromal cells, J. Mater. Sci. Mater. Med. 25 (2014) 1563-1575; https:// doi.org/10.1007/s10856-014-5174-8

31. A. Saadat, A.A. Behnamghader, S. Karbasi, D. Abedi, M. Soleimani and A. Shafiee, Comparison of acellular and cellular bioactivity of poly 3-hydroxybutyrate/hydroxyapatite nanocomposite and poly 3-hydroxybutyrate scaffolds, Biotechnol. Bioprocess Eng. 18 (2013) 587-593; https://doi.org/10.1007/ s12257-012-0744-4

32. Z. Chen, Y. Song, J. Zhang, W. Liu, J. Cui, H. Li and F. Chen, Laminated electrospun nHA/PHBcomposite scaffolds mimicking bone extracellular matrix for bone tissue engineering, Mater. Sci. Eng. C 72 (2017) 341-351; https://doi.org/ 10.1016/j.msec.2016.11.070

33. M. Sadat-Shojai, Electrospun polyhydroxybutyrate/hydroxyapatite nanohybrids: microstructure and bone cell response, J. Mater. Sci. Technol. 32 (2016) 1013-1020; https://doi.org/10.1016/j. jmst.2016.07.007

34. B. Pourmollaabbassi, S. Karbasi and B. Hashemibeni, Evaluate the growth and adhesion of osteoblast cells on nanocomposite scaffold of hydroxyapatite/titania coated with poly hydroxybutyrate, Adv. Biomed. Res. 5 (2016) Article ID 156 (11 pages); https://doi.org/10.4103/2277-9175.188486

35. H. Hajiali, M. Hosseinalipour, S. Karbasi and M. A. Shokrgozar, The influence of bioglass nanoparticles on the biodegradation and biocompatibility of poly(3-hydroxybutyrate) scaffolds, Int. J. Artif. Organs 35 (2012) 1015-1024; https://doi.org/10.5301/ijao.5000119

36. S. K. Misra, T. I. Ansari, S. P. Valappil, D. Mohn, S. E. Philip, W. J. Stark, I. Roy, J. C. Knowles, V. Salih and A. R. Boccaccini, Poly(3-hydroxybutyrate) multifunctional composite scaffolds for tissue engineering applications, Biomaterials 31 (2010) 2806-2815; https://doi.org/10.1016/j.biomaterials.2009.12.045 
37. M. Meischel, J. Eichler, E. Martinelli, U. Karr, J. Weigel, G. Schmöller, E. K. Tschegg, S. Fischerauer, A. M. Weinberg and S. E. Stanzl-Tschegg, Adhesive strength of bone-implant interfaces and in-vivo degradation of PHB composites for load-bearing applications, J. Mech. Behav. Biomed. Mater. 53 (2016) 104-118; https://doi.org/10.1016/j.jmbbm.2015.08.004

38. M. Franceschini, A. Di Matteo, H. Bösebeck, H. Büchner and S. Vogt, Treatment of a chronic recurrent fistulized tibial osteomyelitis: administration of a novel antibiotic-loaded bone substitute combined with a pedicular muscle flap sealing, Eur. J. Orthop. Surg. Traumatol. 22 (2012) 245-249; https:// doi.org/ 10.1007/s00590-012-0956-5

39. L. Medvecky, Microstructure and properties of polyhydroxybutyrate-chitosan-nanohydroxyapatite composite scaffolds, Sci. World J. 2012 (2012) Article ID 537973 (8 pages); https://doi.org/10.1100/ 2012/537973

40. H. Y. Tai, E. Fu, L.-P. Cheng and T.-M. Don, Fabrication of asymmetric membranes from polyhydroxybutyrate and biphasic calcium phosphate/chitosan for guided bone regeneration, J. Polym. Res. 21 (2014) Article ID 421 (12 pages); https://doi.org/10.1007/s10965-014-0421-8

41. M. Giretova, L. Medvecky, R. Stulajterova, T. Sopcak, J. Briancin and M. Tatarkova, Effect of enzymatic degradation of chitosan in polyhydroxybutyrate/chitosan/calcium phosphate composites on in vitro osteoblast response, J. Mater. Sci. Mater. Med. 27 (2016) Article ID 181; https://doi.org/ 10.1007/ s10856-016-5801-7

42. Y. Ding, Q. Yao, W. Li, D. W. Schubert, A. R. Boccaccini and J. A. Roether, The evaluation of physical properties and in vitro cell behavior of $\mathrm{PHB} / \mathrm{PCL} /$ sol-gel derived silica hybrid scaffolds and $\mathrm{PHB} /$ PCL/fumed silica composite scaffolds, Colloids Surf. B Biointerfaces 136 (2015) 93-98; https://doi.org/ 10.1016/j.colsurfb.2015.08.023

43. Y. Ding, W. Li, T. Müller, D. W. Schubert, A. R. Boccaccini, Q. Yao and J. A. Roether, Electrospun polyhydroxybutyrate/poly( $\varepsilon$-caprolactone)/ $58 \mathrm{~S}$ sol-gel bioactive glass hybrid scaffolds with highly improved osteogenic potential for bone tissue engineering, Appl. Mater. Interfaces 8 (2016) 17098-17108; https://doi.org/ 10.1021/acsami.6b03997

44. C. Zhijiang, X. Yi, Y. Haizheng, J. Jia and Y. Liu, Poly(hydroxybutyrate)/cellulose acetate blend nanofiber scaffolds: Preparation, characterization and cytocompatibility, Mater. Sci. Eng. C 58 (2016) 757-767; https://doi.org/ 10.1016/j.msec.2015.09.048

45. A. Venault, A. Subarja and Y. Chang, Zwitterionic polyhydroxybutyrate electrospun fibrous membranes with a compromise of bioinert control and tissue-cell growth, Langmuir 33 (2017) 2460-2471; https://doi.org/ 10.1021/asc.langmuir.6b04683

46. N. Goonoo, A. Bhaw-Luximon, P. Passanha, S. Esteves, H. Schönherr and D. Jhurry, Biomineralization potential and cellular response of PHB and PHBV blends with natural anionic polysaccharides, Mater. Sci. Eng. C 76 (2017) 13-24; https://doi.org/10.1016/j.msec2017.02.156

47. H. Li, H. Pan, C. Ning, G. Tan, J. Liao and G. Ni, Magnesium with micro-arc oxidation coating and polymeric membrane: an in vitro study on microenvironment, J. Mater. Sci. Mater. Med. 26 (2015) Article ID 147; https://doi.org/10.1007/s10856-015-5428-0

48. Y. W. Wang, Q. Wu and G. Q. Chen, Attachment, proliferation and differentiation of osteoblasts on random biopolyester poly(3-hydroxybutyrate-co-3-hydroxyhexanoate) scaffolds, Biomaterials 25 (2004) 669-675; https://doi.org/ 10.1016/S0142-9612(03)00561-1

49. M. Sadat-Shojai, M. T. Khorasani and A. Jamshidi, A new strategy for fabrication of bone scaffolds using electrospun nano-Hap/PHB fibers and protein hydrogels, Chem. Eng. J. 289 (2016) 38-47; https://doi.org/ 10.1016/j.cej.2015.12.079

50. S. W. Peng, X. Y. Guo, G. G. Shang, J. Li, X. Y. Xu, M. L. You, P. Li and G. Q. Chen, An assessment of the risk of carcinogenicity associated with polyhydroxyalkanoates through an analysis of DNA aneuploid and telomerase activity, Biomaterials 32 (2011) 2546-2555; https://doi.org/10.1016/j.biomaterials.2010.12.051 
51. A. Q. Ali, T. P. Kannan, A. Ahmad and Ab. R. Samsudin, In vitro genotoxicity tests for polyhydroxybutyrate-A synthetic biomaterial, Toxicol. in Vitro 22 (2008) 57-67; https://doi.org/10.1016/j.tiv.2007.08.001

52. Y. Wang, X. L. Jiang, S. W. Peng, X. Y. Guo, G. G. Shang, J. C. Chen, Q. Wu and G. Q. Chen, Induced apoptosis of osteoblasts proliferating on polyhydroxyalkanoates, Biomaterials 34 (2013) 3737-3746; https://doi.org/10.1016/j.biomaterials.2013.01.088

53. C. Rentsch, B. Rentsch, A. Breier, A. Hofmann, S. Manthey, D. Scharnweber and H. Zwipp, Evaluation of the osteogenic potential and vascularization of 3D poly(3)hydroxybutyrate scaffolds subcutaneously implanted in nude rats, J. Biomed. Mater. Res. A 92A (2010) 185-195; https://doi.org/ 10.1002/jbm.a.32314

54. Z. Karahaliloğlu, B. Ercan, E. N. Taylor, S. Chung, E. B. Denkbas and T. J. Webster, Antibacterial nanostructured polyhydroxybutyrate membranes for guided bone regeneration, J. Biomed. Nanotechnol. 11 (2015) 2253-2263; https://doi.org/10.1166/jbn.2015.2106

55. I. Rozila, P. Azari, S. Munirah, W. K. Z. W. Safwani, S. N. Gan, A. G. N. Azurah, J. Jahendran, B. Pingguan-Murphy and K. H. Chua, Differential osteogenic potential of human adipose-derived stem cells co-cultured with human osteoblasts on polymeric microfiber scaffolds, J. Biomed. Mater. Res. A 104A (2016) 377-387; https://doi.org/10.1002/jbm.a.35573

56. P. Slepička, I. Michaljaničová, S. Rimpelová and V. Švorčík, Surface roughness in action - Cells in opposition, Mater. Sci. Eng. C 76 (2017) 818-826; https://doi.org/10.1016/j.msec.2017.03.061

57. H. E. Bernd, C. Kunze, T. Freier, K. Sternberg, S. Kramer, D. Behrend, F. Prall, M. Donat and B. Kramp, Poly(3-hydroxybutyrate) (PHB) patches for covering anterior skull base defects - an animal study with minipigs, Acta Otolaryngol. 129 (2009) 1010-1017; https://doi.org/10.1080/00016480802552493

58. T. Gredes, T. Gedrange, C. Hinüber, M. Gelinsky and C. Kunert-Keil, Histological and molecularbiological analyses of poly(3-hydroxybutyrate) (PHB) patches for enhancement of bone regeneration, Ann. Anat. 199 (2015) 36-42; https://doi.org/ 10.1016/j.aanat.2014.04.003

59. E. G. L. Alves, C. M. F. Rezende, R. Serakides, M. M. Pereira and I. R. Rosado, Orthopedic implant of a polyhydroxybutyrate (PHB) and hydroxyapatite composite in cats, J. Feline Med. Surg. 13 (2011) 546-552; https://doi.org/ 10.1016/j.jfms.2011.03.002

60. A. Celarek, T. Kraus, E. K. Tschegg, S. F. Fischerauer, S. Stanzl-Tschegg, P. J. Uggowitzer and A. M. Weinberg, PHB, crystalline and amorphous magnesium alloys: Promising candidates for bioresorbable osteosynthesis implants? Mater. Sci. Eng. C 32 (2012) 1503-1510; https://doi.org/10.1016/j. msec.2012.04.032 